\title{
Peningkatan Keterampilan Pemasaran Melalui Pelatihan Whatsapp Business Pada UMKM
}

\author{
Andy Prasetyo Wati ${ }^{1)}$, Jefry Aulia Martha ${ }^{2)}$, Aniek Indrawati ${ }^{3)}$ \\ ${ }^{1,2,3)}$ Fakultas Ekonomi, Universitas Negeri Malang \\ andy.prasetyo.fe@um.ac.id
}

\begin{abstract}
ABSTRAK: Malang memiliki banyak produk unggulan yang diproduksi oleh UMKM, mulai dari makanan, minuman bahkan sampai dengan kerajinan tangan (crafting). Mengingat semakin pesatnya perpindahan informasi melalui media digital dan pengguna digital serta berdasar dari data kualitatif dan kuantitatif diatas, maka dapat disimpulkan bahwa di Kabupaten Malang cukup banyak pelaku UMKM dengan berbagai permasalahannya yang belum mampu untuk melaksanakan system pemasaran menggunakan digital marketing dengan efektif. Keterampilan dalam menguasai digital marketing sangat penting diberikan kepada pelaku UMKM di Malang, karena: Pertama, mereka belum menguasi pemasaran berbasis digital dengan efektif sehingga belum memanfaatkan digital marketing secara maksimal. Kedua, tanpa memiliki kompetensi ini (penguasaan digital marketing), maka akan menyulitkan para pelaku UMKM di Malang bersaing dalam perdagangan, sehingga keterampilan ini penting diberikan terlebih dahulu kepada para pelaku UMKM di Malang sebelum melakukan pendampingan kearah yang lainnya. Adapun UMKM yang dijadikan objek pelatihan adalah UMKM Perum GPA Ngijo, Karangploso Kabupaten Malang. Teknik pendampingan yang digunakan adalah teknik pendampingan terarah yang disesuaikan dengan kebutuhan. Hasil positif dan memuaskan dari pelatihan pemasaran berbasis digital ini merupakan langkah awal yang dilakukan team pengabdian dalam membantu pelaku usaha mikro kecil dan menengah untuk meningkatkan frekuensi penjualan.
\end{abstract}

Kata kunci: Digital Marketing, Whatsapp Business, UMKM

ABSTRACT: Malang has many excellent products produced by UMKM, ranging from food, beverages and even handicrafts. Given the rapid transfer of information through digital media and digital users and based on the qualitative and quantitative data above, it can be concluded that in Malang Regency there are quite a lot of UMKM players with various problems who have not been able to implement a marketing system using digital marketing effectively. The skills in mastering digital marketing are very important to be given to UMKM players in Malang, because: First, they have not mastered digital-based marketing effectively so they have not taken full advantage of digital marketing. Second, without having this competency (mastery of digital marketing), it will make it difficult for UMKM players in Malang to compete in trade, so this skill is important to be given first to MSME players in Malang before providing assistance towards others. The UMKM that was used as the object of the training were UMKM Perum GPA Ngijo, Karangploso, Kabupaten Malang. The mentoring technique used is directed mentoring technique that is tailored to the needs. The positive and satisfying results of the digital-based marketing training which the first steps taken by the service team in helping micro, small and medium enterprises to increase the frequency of sales.

Keywords: Digital Marketing, Whatsapp Business, UMKM

\section{PENDAHULUAN}

Perkembangan di era globalisasi telah menciptakan era digital yang semakin pesat. Situasi ini menuntut berbagai pihak untuk mampu beradaptasi dengan lingkungan baru, tidak terkecuali dengan para pelaku usaha, baik pelaku usaha dalam skala kecil, menengah maupun besar. Perkembangan dalam era digital, tidak hanya menyentuh 
proses produksi, pendidikan maupun komunikasi, akan tetapi juga menyentuh proses dalam memperkenalkan serta menjual produk dengan intensitas yang sangat cepat. Dengan menggunakan internet sebagai media dalam perdagangan, UMKM memiliki peluang yang sangat besar dalam kontribusi rantai perekonomian global, UMKM dapat menjual produknya lebih cepat dan dengan menggunakan media digital dalam proses pemasaran serta penjualannya, maka dapat mengurangi biaya operasional termasuk biaya distribusi yang sangat tinggi. Tantangan yang perlu dihadapi oleh pelaku Usaha Mikro Kecil Menengah (UMKM) di era ekonomi digital ini adalah masih rendahnya kemampuan sumber daya manusia (SDM) dalam menghadapi metode perdagangan dari konvensional menjadi berbasis digital.

Malang memiliki banyak produk unggulan yang diproduksi oleh UMKM, mulai dari makanan, minuman bahkan sampai dengan kerajinan tangan (crafting). Akan tetapi, data dari Dinas Koperasi dan UMKM Kabupaten Malang, baru 30\% dari 70.000 UMKM yang melakukan pemasaran dalam perdagangan menggunakan digital marketing, $70 \%$ sisanya menggunakan system pemasaran tradisional dalam perdagangan. Sedangkan dalam era digital, kecepatan dalam memproduksi barang dan kualitas yang dihasilkan bukan lagi menjadi ukuran utama untuk mendongkrak penjualan, karena konsumen pada era ini lebih menyukai melakukan pembelian melalui platform marketplace berbasis digital, alasan konsumen sangat sederhana, mereka tidak perlu bersusah payah pergi ke toko dan memilih produk yang diinginkan. Pemborosan waktu untuk berbelanja secara tradisional inilah yang membuat mereka lebih memilih untuk berbelanja lewat media teknologi berbasis internet. Hal ini terbukti dari hasil riset HootSuite dan agensi marketing sosial We Are Social yang dirilis pada Januari 2020, bahwa total penduduk Indonesia yang telah menggunakan internet mencapai 175,4 juta orang dari total populasi penduduk Indonesia sebesar 272,1 juta. Artinya, penggunaan internet di Indonesia telah meningkat tajam, yaitu sebesar $17 \%$ dibanding dengan penggunaan internet pada tahun 2019. Selain itu, hasil penelitian ini juga menyebutkan bahwa 59\% penggunaan internet oleh masayarakat di Indonesia digunakan untuk mengakses media social (Ludwianto, 2020). Melihat animo masyarakat terhadap penggunaan internet, khususnya pada penggunaan media social, maka para pelaku UMKM di Malang harus berani untuk merubah pemasaran mereka dari tradisional menjadi berbasis digital. Jika tidak mampun untuk menggunakan pemasaran berbasis digital yang berbayar, maka mereka bisa memanfaatkan pemasaran berbasis digital yang gratis dan sudah digunakan sehari-hari, misalnya dengan menggunakan facebook, Instagram, whatsapp dan line.

Pelaku UMKM yang telah mempromosikan produknya melalui platform marketplace berbasis digital yang ada di Indonesia pada umumnya berasal dari luar negeri, hal ini membuktikan bahwa digital marketing mampu untuk menyentuh konsumen secara intens dan langsung meskipun tidak berada dalam wilayah yang sama, yang artinya konsumen era digital ini lebih memilih menggunakan digital marketing 
dalam mendapatkan produk yang diinginkannya. Hal ini terbukti dari penelitian yang dilakukan oleh Business2Community yang menghasilkan bahwa terdapat beberapa tingkat kepercayaan terhadap iklan oline yang disajikan dalam Tabel 1.

Tabel 1. Tingkat Kepercayaan Konsumen melalui Digital Marketing

\begin{tabular}{clc}
\hline No & \multicolumn{1}{c}{ Jenis Digital Marketing } & Presentase (\%) \\
\hline 1. & Search Engine & 57 \\
\hline 2. & Sosial Media & 53 \\
\hline 3. & Video Online & 52 \\
\hline 4. & Online Banner & 47 \\
\hline
\end{tabular}

(Sumber: Data Diolah Peneliti, 2020)

Perkembangan teknologi yang semakin pesat membuat berbagai kalangan dalam dunia bisnis harus mampu memanfaatkan media pemasaran berbasis teknologi sehingga informasi produk akan lebih cepat sampai pada konsumen. Hal ini sesuai dengan penelitian yang telah dilakukan Sarafino \& Smith (2011) yang menghasilkan bahwa sebesar $88 \%$ produsen atau penjual telah memanfaatkan media social sebagai alat dalam system pemasaran. Hal ini senada dengan pendapat Müller, Dreier, Beutel, Duven, Giralt, \& Wölfling (2016) yang menyatakan bahwa para pengusaha dapat menggunakan berbagai sarana media social yang ada dalam mengembangkan hubungannya antara pengusaha dan para pelanggan dalam meningkatkan pengembalian investasi yang lebih tinggi.

\section{PERMASALAHAN}

Mengingat semakin pesatnya perpindahan informasi melalui media digital dan pengguna digital serta berdasar dari data kualitatif dan kuantitatif diatas, maka dapat disimpulkan bahwa di Kabupaten Malang cukup banyak pelaku UMKM dengan berbagai permasalahannya yang belum mampu untuk melaksanakan system pemasaran menggunakan digital marketing dengan efektif. Keterampilan dalam menguasai digital marketing sangat penting diberikan kepada pelaku UMKM di Malang, karena: Pertama, mereka belum menguasi pemasaran berbasis digital dengan efektif sehingga belum memanfaatkan digital marketing secara maksimal. Kedua, tanpa memiliki kompetensi ini (penguasaan digital marketing), maka akan menyulitkan para pelaku UMKM di Malang bersaing dalam perdagangan, sehingga keterampilan ini penting diberikan terlebih dahulu kepada para pelaku UMKM di Malang sebelum melakukan pendampingan kearah yang lainnya. Adapun UMKM yang dijadikan objek pelatihan adalah UMKM Perum GPA Ngijo, Kecamatan Karangploso Kabupaten Malang.

\section{METODE PELAKSANAAN}

Teknik pendampingan yang digunakan adalah teknik pendampingan terarah yang disesuaikan dengan kebutuhan, sedangkan materi pelatihan meliputi pengenalan 
digital marketing dan pemanfaatan digital marketing yang dapat digunakan dalam meningkatkan penjualan produk UMKM serta dapat bersaing secara maksimal dengan produk-produk di luar Malang. Digital marketing sendiri merupakan sebuah system pemasaran yang memanfaatkan media elektronik yang tersambung ke internet. Sehingga, digital marketing dapat dikatakan sebagai sebuah aktivitas, instutusi atau aturan yang berlaku dan proses dalam pemasaran yang menggunakan fasilitas berbasis teknologi digital. Kegiatan yang dilakukan pelaku usaha tersebut digunakan untuk menciptakan, memberikan nilai dan mengkomunikasikan atas produk tersebut kepada pelanggan dan para pemilik kepentingan lainnya terhadap produk tersebut (Kannan \& $\mathrm{Li}, 2017)$.

Adapun target dalam pendampingan digital marketing yang difokuskan pada whatsapp business oleh team pengabdian kepada masyarakat adalah pelaku UMKM di Perum GPA, Ngijo, Kecamatan Karaploso Kabupaten Malang. Berdasarkan identifikasi terhadap permasalahan mitra di atas, maka kami berinisiatif untuk memberikan solusi permasalahan mitra tersebut dengan memberikan keterampilan pemasaran melalui pelatihan whatsapp business.

\section{PELAKSANAAN}

Kegiatan pengabdian ini dilakukan pada hari Sabtu, 25 Juli 2020 yang bertempat di Balai Rukun Warga (RW) Perum GPA, Ngijo, Karangploso, Kabupaten Malang. Adapun peserta pelatihan yang hadir terdiri dari perwakilan UMKM setiap Rukun Tetangga (RT) yang hadir. Terdapat 20 orang perwakilan yang menghadiri pelatihan, harapannya perwakilan tersebut akan menularkan keterampilan yang telah diajarkan kepada pemilik usaha mikro kecil dan menengah di lingkungannya masing-masing. Sedangkan kegiatan dalam pendampingan ini meliputi:

1. Pemaparan materi tentang konsep dari digital marketing dan bagaimana cara pemakaian digital marketing yang efektif dalam penjualan sehingga mampu menarik minat konsumen.

2. Pemaparan pemanfaatan teknologi dalam pemasaran.

3. Pendampingan pembuatan content narasi yang unik dalam menawarkan produk pada media social.

4. Pendapingan dalam mengaplikasikan Whatsapp Business.

\section{HASIL DAN LUARAN}

Pelatihan ini, media digital marketing yang dimaksud lebih difokuskan kepada media whatsapp business, hal ini dikarenakan media whatsapp tersebut selalu digunakan untuk berkomunikasi oleh mayarakat, khususnya disini oleh para pelaku UMKM di Perum GPA, Ngijo, Karaploso, Kabupaten Malang. Menurut halaman resmi whatsapp, dalam whatsapp business, pelaku UMKM dapat dengan mudah membuat katalog produk dan mempromosikannya kepada calon pelanggan, selain itu, pelaku 
UMKM juga dapat menggunakan pesan otomatis serta menanggapi pesan dengan cepat karena ada menu penyortir pesan. Selain itu, whatsapp business memiliki menu labels yang dapat digunakan para pelaku bisnis khususnya UMKM untuk mengkategorikan pesan masuk tertentu, hal ini akan berdampak pada lebih terorganisasinya pelaku bisnis dengan para konsumen dalam melakukan komunikasi. Perangkat berbasis teknologi khususnya seluler, telah memberikan kontribusi yang cukup signifikan dalam penjualan. Hal ini terbukti dari kecepatan penjualan yang cukup tinggi di semua penjualan berbasis online, yaitu antara 22\% dan 27\% (Rao, 2015; Malcom, 2015; Kannan \& Li, 2017).

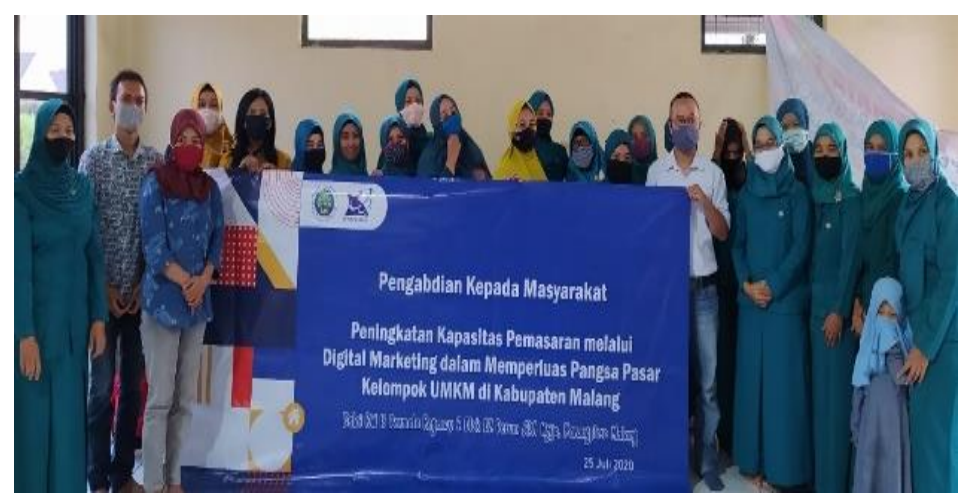

\section{Gambar 1. Peserta Pelatihan dan Team Pengabdian Kepada Masyarakat}

Kegiatan pengabdian ini diawali dengan pemaparan materi yang menjelaskan tentang konsep dari digital marketing dan bagaimana cara pemakaian digital marketing yang efektif dalam penjualan sehingga mampu menarik minat konsumen. Karena pada dasarnya, digital marketing merupakan sebuah kegiatan dalam pemasaran yang mencakup branding akan produk, kegiatan ini sendiri selalu menggunakan media yang berbasis teknologi, seperti website, whatsapp baik regular maupun business, facebook, instragram, e-mail, blog, dan lain sebagainya (Sanjaya \& Tarigan, 2009).

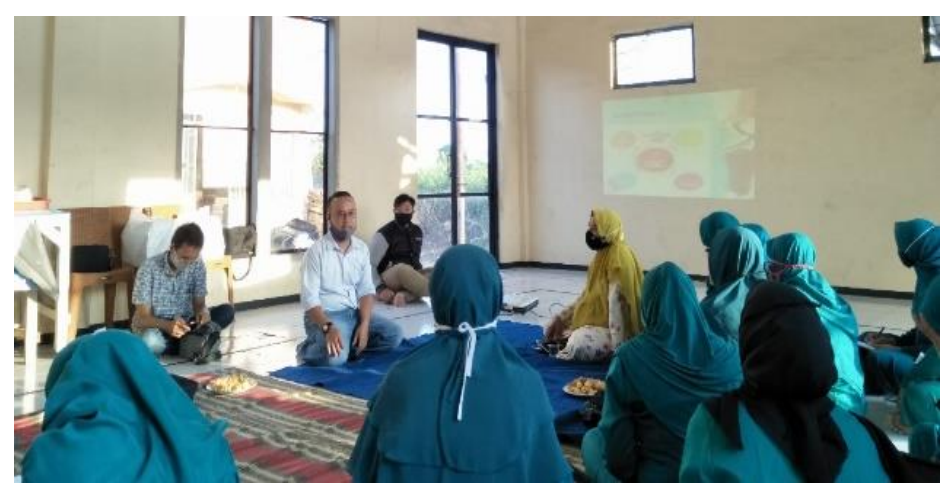

Gambar 2. Pemaparan Materi 
Antusiasme dari peserta diwujudkan dengan adanya beberapa pertanyaan yang terkait dengan pemasaran berbasis digital ini. Salah satunya adalah bagaimana trik yang dapat dilakukan oleh pelaku bisnis dalam skala usaha mikro kecil dan menengah untuk dapat bersaing dalam dunia bisnis atau perdagangan. Konsep yang dibagi oleh narasumber untuk menciptakan daya saing yang bagus dalam dunia usaha yaitu tentang bagaimana pelaku usaha, khususnya UMKM, harus mampu memposisikan produk mereka dengan tepat di benak konsumen, hal ini tentunya berkaitan dengan citra merek yang dimiliki. Citra merek atau brand image merupakan sebuah perlakuan yang melekat pada benak atau ingatan pelanggan terhadap sebuah produk atau jasa (Kotler, 2009). Hasilnya adalah, jika produsen telah mampu membuat para konsumen ingat akan produk mereka, maka konsumen akan melakukan pembelian berulang kali terhadap produk yang mereka produksi. Artinya, para pelaku usaha mikro kecil dan menengah ini harus mampu untuk membuat produk yang mereka produksi dapat dengan mudah diingat oleh konsumen. Salah satu hal yang dicontohkan oleh narasumber dalam melakukan citra merek terhadap produk yang dimiliki adalah dengan memberikan keunikan rasa atau bahkan keunikan dalam memberikan merek terhadap produk. Sebagai contoh keunikan terhadap merek pada produk UMKM di Malang antara lain "Coklat Apel Matur, Coklat Tempe De Konco dan Ledre Cokelat" (Rutmawati, 2017). Sedangkan contoh dari produk dan cara pemasaran yang masih sederhana dalam penyertaan konten pemasaran dalam media sosial dari UMKM Perum GPA, Ngijo, Karangploso Kabupaten Malang disajikan dalam Gambar 3a dan 3b.
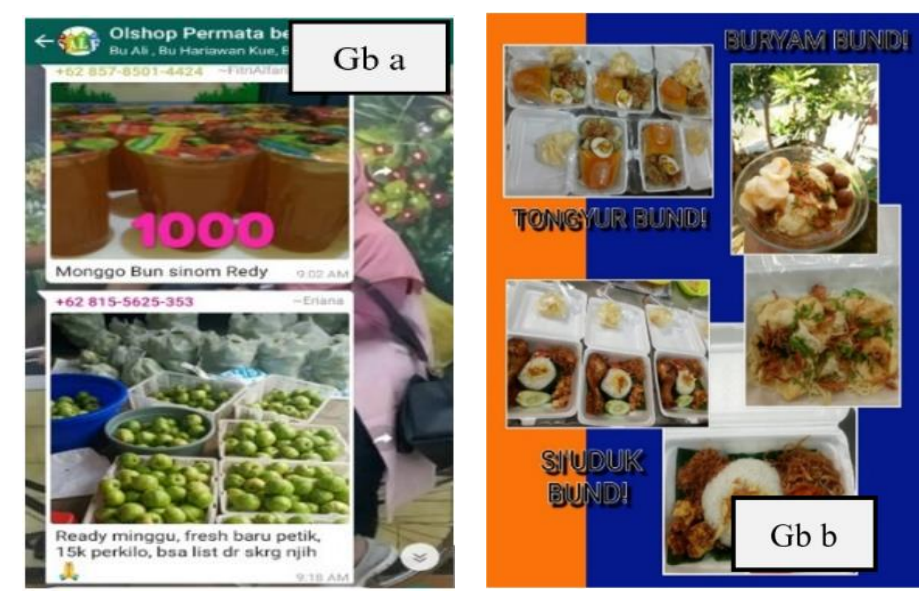

Gambar 3. a) Merek pada salah satu produk dan, b) Salah satu content pemasaran pada media sosial standar

Kegiatan selanjutnya adalah dengan memberikan pendampingan pembuatan content narasi yang unik dalam menawarkan produknya sehingga mampu menarik minat pelanggan kepada perwakilan pelaku usaha mikro kecil dan menengah di Perum 
GPA Ngijo, Karangploso Kabupaten Malang. Dalam pemasaran, content dari narasi sebuah produk merupakan salah satu hal yang akan menarik perhatian konsumen dalam melakukan pembelian. Hal ini dikarenakan kontent atau narasi dalam sebuah pemasaran merupakan suatu strategi yang dibuat oleh produsen untuk menarik minat baik minat pelanggan baru maupun pelanggan yang telah memiliki loyalitas terhadap produk tersebut. Tujuan dengan tidak memisahkan subjek penerima dari pembuatan content dalam pemasaran adalah untuk memperkenalkan dan mempromosikan produk sehingga menarik minat pelanggan dan mempertahankan loyalitas pelanggan (Darmawan, 2015; Abiyyuansyah, Kusumawati \& Irawan, 2019). Selain itu content dalam pemasaran juga sangat diperlukan oleh para pelaku bisnis khususnya UMKM, hal ini dikarenakan content dalam pemasaran merupakan sebuah strategi dalam pemasaran yang meliputi merencanakan, membuat serta mendistribusikan content sehingga mampu menarik perhatian konsumen. Tujuan dari kegiatan dalam menarik perhatian konsumen ini adalah untuk mendorong mereka sebagai pelanggan tetap atau loyal (Kotler, 2017).

Kegiatan selanjutnya adalah dengan memaparkan pemanfaatan teknologi dalam pemasaran. Teknologi yang dipilih dalam meningkatkan pemasaran dalam pelatihan kali ini lebih menekankan pada whatsapp business. Hal ini dikarenakan, dalam media social berupa whatsapp paling banyak digunakan oleh para pelaku ekonomi UMKM di Perum GPA, Ngijo, Karangploso Kabupaten Malang. Pelatihan penggunaan media social dalam meningkatkan pemasaran juga di dukung oleh hasil penelitian Priambada pada tahun 2017 yang menghasilkan bahwa media social memiliki peran yang cukup baik positif dalam pemasaran produk, hal ini terbukti bahwa $87,8 \%$ mereka menggunakan media whatsapp dalam mempromosikan produknya, sedangkan sisanya menggunakan Facebook dan Instagram yaitu sebesar 75,6\% dan 58,5\%. Selain itu, media social dapat digunakan oleh UMKM sebagai sarana untuk mencapai tujuan promosi atau iklan, kemudian penggunaan media social tersebut dapat digunakan juga sebagai galeri, mengupdate produk, sharing ide serta update status usaha yang digunakan untuk tujuan branding. Sehingga dapat dikatakan bahwa tujuan utama dalam penggunaan media social oleh pelaku usaha dalam pemasasaran yaitu sebagai sarana interaksi dengan para pelanggan, selain itu juga dapat digunakan sebagai alat evaluasi tingkat kebutuhan pasar serta sebagai alat guna mendapatkan masukan, kritik ataupun saran dari konsumen terhadap produk yang dijual (Seth, 2012).

Setelah memberikan pemahaman tentang strategi bersaing dengan memanfaatkan teknologi yang tepat, maka kegiatan selanjutnya adalah melakukan pengaplikasian digital marketing. Kegiatan ini dilakukan dengan tetap menggunakan system pendampingan. Langkah awal dalam praktik pemasaran dengan menggunakan whatsapp business adalah dengan mempersiapkan foto produk yang sudah dimiliki pelaku usaha dan smart phone yang telah terinstal whatsapp business. Langkah kedua adalah dengan mengisi beberapa informasi yang dibutuhkan dalam fitur whatsapp business yang disesuaikan dengan kebutuhan produsen dalam mempromosikan 
produknya, kegiatan pendampingan dilakukan sampai peserta dapat mengupload dan memberikan narasi yang menarik pada photo produk. Adapun contoh photo produk UMKM GPA, Ngijo, Karangploso Kabupaten Malang yang siap di upload dalam whatsapp business disajikan pada Gambar 4.

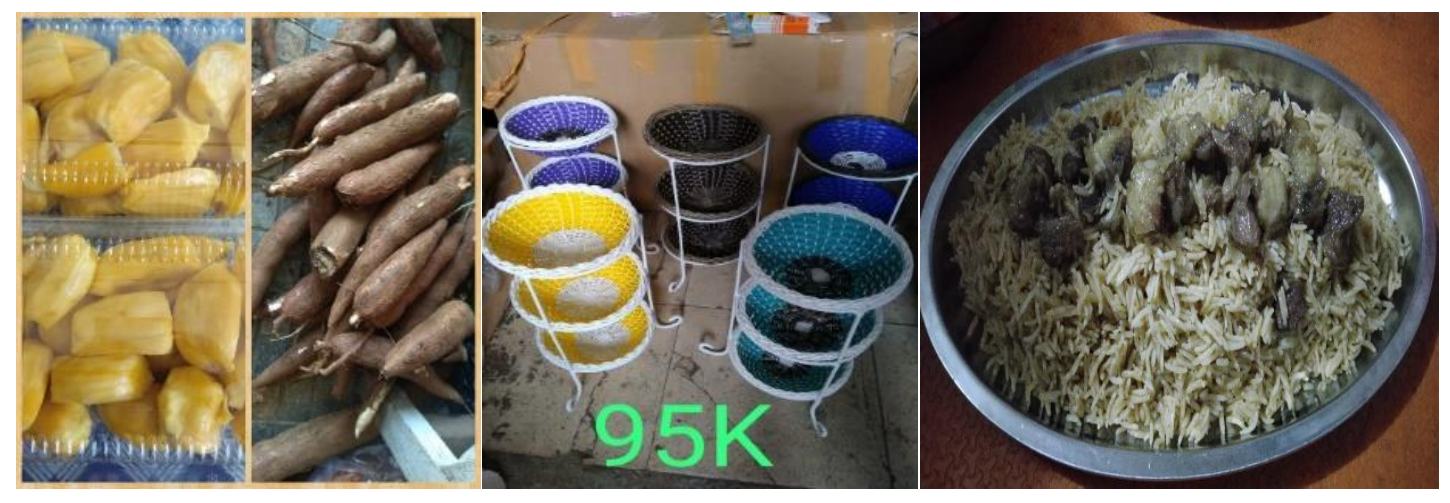

Gambar 4. Contoh Produk UMKM GPA Ngijo

Hasil pelatihan keterampilan pemasaran menggunakan whatsapp business dalam upaya peningkatan penjualan dan memiliki daya saing di dunia usaha sangat memuaskan. Hal ini terlihat dari antusiasme dari para peserta untuk melakukan upload produk dan pengisian content dalam whatsapp business.

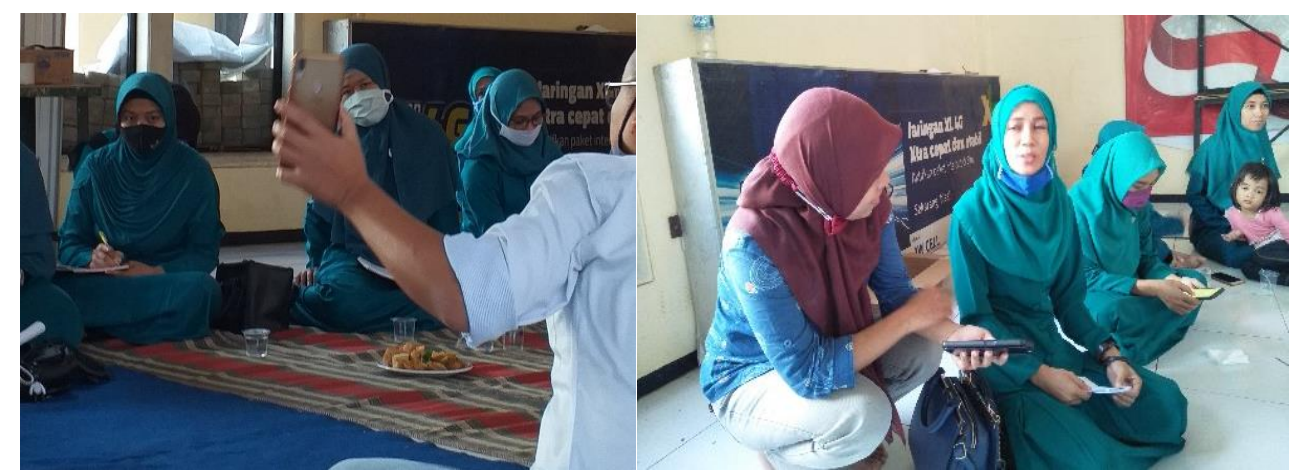

Gambar 5. Proses pendampingan penggunaan whatsapp business

Selain itu, para perwakilan UMKM ini langsung menerapkan pelatihan menggunakan whatsapp business yang langsung didampingi oleh narasumber dan team pengabidan. Banyak kendala yang dihadapi oleh para peserta waktu pelaksanaan pendampingan, kendala tersebut antara lain kurang menariknya gambar produk yang dimiliki, sehingga perlu adanya pendampingan yang lebih intesif tentang penentuan tampilan produk yang tepat dalam pemasaran. Salah satunya adalah dari sisi tampilan dan pencahayaan gambar produk yang lebih menarik, selain dari sisi pembuatan content 
atau narasi yang mendampingi gambar dari produk untuk di upload dalam whatsapp business nantinya.

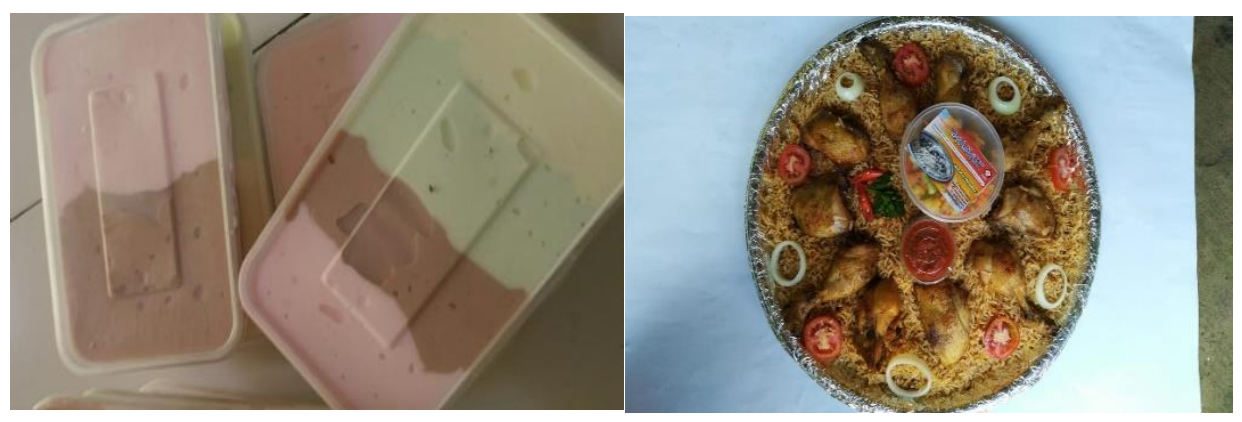

Gambar 6. Photo produk UMKM GPA, Ngijo, Karangploso Kabupaten Malang

Cara pengambilan gambar pada objek produk juga merupakan salah satu penentu dalam menarik minat calon konsumen maupun konsumen yang telah loyal untuk membeli produk yang diproduksi. Hal ini dikarenakan, visual content marketing yang tepat akan sangat mempengaruhi konsumen untuk memberikan keputusan apakah mereka akan membeli produk tersebut atau malah dengan cepat meninggalkan produk dan mengabaikannya. Adapun tampilan dari hasil pendampingan dari peserta pelatihan digital marketing menggunakan media whatsapp business.
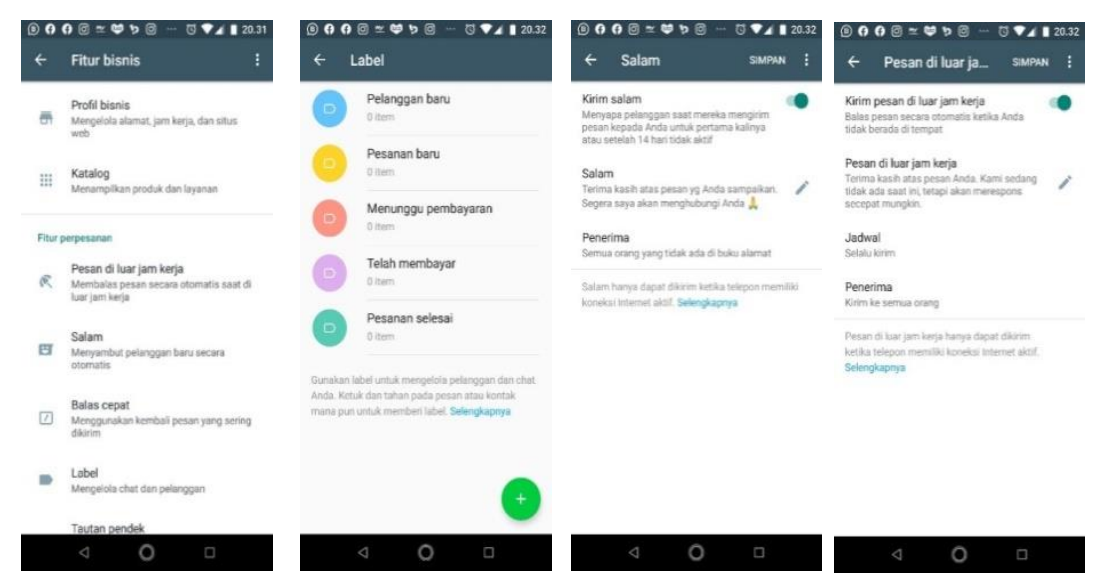

\section{Gambar 7. Tampilan Whatsapp Business Peserta Pendampingan}

Pelatihan menggunakan whatsapp business pada pelaku usaha mikro kecil dan menengah di Perum GPA, Ngijo, Karangploso Kabupaten Malang diharapkan dapat meningkatkan penjualan produk serta dapat bersaing secara maksimal. Disamping itu, dengan menggunakan salah satu media digital dalam pemasarannya, pelaku usaha mikro kecil dan menengah ini dapat segera mengembangkan bisnisnya kearah yang lebih besar dan terorganisir, hal ini dikarenakan dengan menggunakan whatsapp business mereka 
dapat dengan mudah melakukan control terhadap pesanan, pembayaran dan pelanggan baru.

\section{KESIMPULAN}

Pelatihan pemasaran berbasis digital yang lebih dispesifikkan dengan menggunakan media whatsapp business pada UMKM Perum GPA, Ngijo, Karangploso Kabupaten Malang ini merupakan langkah awal yang dilakukan team pengabdian dalam membantu pelaku usaha mikro kecil dan menengah untuk meningkatkan frekuensi penjualan. Hal ini dikarenakan masih banyak pelaku usaha khususanya mereka yang bergerak di sector usaha mikro kecil dan menengah yang masih belum mampu untuk menerapkan pemasaran berbasis digital secara maksimal. Kurang maksimalnya penggunaan media digital khususnya social media dalam pemasaran dikarenakan kurang pahamnya pelaku UMKM ini akan kemampuan media social dalam menarik minat konsumen atau calon konsumen, tentunya dengan menggunakan content narasi dan gambar yang tepat.

Harapannya, setelah dilakukan pendampingan dan pelatihan terhadap system pemasaran berbasis digital ini, pelaku UMKM, khususnya UMKM Perum GPA, Ngijo, Karangploso Kabupaten Malang ini mampu dengan mudah untuk meningkatkan penjualan dan meningkatkan perekonomian, baik perekonomian individu maupun perekonomian sekitar.

\section{DAFTAR PUSTAKA}

Abiyyuansyah, F., Kusumawati, A., \& Irawan, A. 2019. Analisis Implementasi Strategi Content Marketing Dalam Meningkatkan Customer Engagement (Studi pada Strategi Content Marketing Amstirdam Coffee Malang). Jurnal Administrasi Bisnis. 73(1): p. 78-87.

Kannan, P. K. 2017. Digital marketing: A framework, review and research agenda. International Journal of Research in Marketing. 34(1): p. 22-45.

Kotler, P. 2009. Manajemen Pemasaran. Jakarta: Erlangga.

Kotler, P., Kartajaya, H., \& Setiawan, I. 2017. Marketing 4.0: Moving from Traditional to Digital. New Jersey: John Wiley \& Sons.

Ludwianto, B. 2020. Riset: 64\% Penduduk Indonesia Sudah Pakai Internet. (online). (https://kumparan.com/kumparantech/riset-64-penduduk-indonesia-sudahpakai-internet-1ssUCDbKILp/full), Accessed on Agustus 25th 2020.

Müller, K. W., Dreier, M., Beutel, M. E., Duven, E., Giralt, S., \& Wölfling, K. 2016. A hidden type of internet addiction? Intense and addictive use of social networking sites in adolescents. Computers in Human Behavior. 55: p. 172-177.

Priambada, S. 2017. Potensi Media Sosial Bagi Usaha Kecil Dan Menengah (UKM) di Malang Raya. SESINDO. 
Rutmawati, S. 2017. Kemeriahan Parade UMKM BRI di Malang, hadirkan 122 pelaku usaha. (Online). (https://malang.merdeka.com/foto/kabar-malang/kemeriahanparade-umkm-bri-di-malang-hadirkan-122-pelaku-usaha-170519v/kemeriahanparade-umkm-bri-di-malang-hadirkan-122-pelaku-usaha-170519v-007.html), Accessed on Agustus 25th 2020.

Sanjaya, Ridwan \& Tarigan, Josua. 2009. Creative Digital Marketing Teknologi Berbiaya Murah, Inovatif dan Berdaya Hasil Gemilang. Jakarta: PT Alex Media Komputindo.

Sarafino, E.P., \& Smith, T.W. 2011. Health Psychology Biopsychosocial Interactions Edisi 7. USA: John Wiley \& Sons, Inc.

Seth, G. 2012. Analyzing the effects of social media on the hospitality industry. (Online). (digitalscholarship.unlv.edu), Accessed on Agustus 25th 2020.

Whatsapp. 2020. WhatsApp Business App. (Online), (https://www.whatsapp.com/business/? lang=en), Accessed on Agustus 25th 2020. 
Volume 4, Nomor 2, September 2020 